\title{
Oceanibulbus indolifex gen. nov., sp. nov., a North Sea alphaproteobacterium that produces bioactive metabolites
}

\author{
Irene Wagner-Döbler, ${ }^{1}$ Holger Rheims,${ }^{1} \dagger$ Andreas Felske, ${ }^{1}$ \\ Aymen El-Ghezal, ${ }^{2}$ Dirk Flade-Schröder, ${ }^{2}$ Hartmut Laatsch, ${ }^{3}$ \\ Siegmund Lang, ${ }^{2}$ Rüdiger Pukall ${ }^{4}$ and Brian J. Tindall ${ }^{4}$ \\ 'GBF - Gesellschaft für Biotechnologische Forschung, D-38124 Braunschweig, Germany \\ ${ }^{2}$ Technical University of Braunschweig, D-38106 Braunschweig, Germany \\ 3University of Göttingen, D-37077 Göttingen, Germany \\ ${ }^{4}$ DSMZ - Deutsche Sammlung von Mikroorganismen und Zellkulturen, D-38124 Braunschweig, \\ Germany
}

Correspondence Irene Wagner-Döbler iwd@gbf.de

\begin{abstract}
A water sample from the North Sea was used to isolate the abundant heterotrophic bacteria that are able to grow on complex marine media. Isolation was by serial dilution and spread plating. Phylogenetic analysis of nearly complete 16S rRNA gene sequences revealed that one of the strains, HEL $-45^{\top}$, had $97 \cdot 4 \%$ sequence similarity to Sulfitobacter mediterraneus and $96.5 \%$ sequence similarity to Staleya guttiformis. Strain $\mathrm{HEL}-45^{\top}$ is a Gram-negative, non-motile rod and obligate aerobe and requires sodium and 1-7\% sea salts for growth. It contains storage granules and does not produce bacteriochlorophyll. Optimal growth temperatures are $25-30^{\circ} \mathrm{C}$. The DNA base composition ( $\mathrm{G}+\mathrm{C}$ content) is $60 \cdot 1 \mathrm{~mol} \%$. Strain HEL- $45^{\top}$ has $\mathrm{Q} 10$ as the dominant respiratory quinone. The major polar lipids are phosphatidyl glycerol, diphosphatidyl glycerol, phosphatidyl choline, phosphatidyl ethanolamine and an aminolipid. The fatty acids comprise $18: 1 \omega 7 c, 18: 0,16: 1 \omega 7 c, 16: 0,3-\mathrm{OH} 10: 0,3-\mathrm{OH} 12: 1$ (or 3-oxo 12:0) and traces of an 18:2 fatty acid. Among the hydroxylated fatty acids only $3-\mathrm{OH}$ $12: 1$ (or 3-oxo 12:0) appears to be amide linked, whereas 3-OH 10:0 appears to be ester linked. The minor fatty acid components (between 1 and $7 \%$ ) allow three subgroups to be distinguished in the Sulfitobacter/Staleya clade, placing $\mathrm{HEL}-45^{\top}$ into a separate lineage characterized by the presence of 3-OH $12: 1$ (or 3-oxo 12:0) and both ester- and amide-linked $16: 1 \omega 7 c$ phospholipids. HEL $-45^{\top}$ produces indole and derivatives thereof, several cyclic dipeptides and thryptanthrin. Phylogenetic analysis of 16S rRNA gene sequences and chemotaxonomic data support the description of a new genus and species, to include Oceanibulbus indolifex gen. nov., sp. nov., with the type strain HEL-45 ${ }^{\top}$ (=DSM $14862^{\top}$ $=$ NCIMB $13983^{\top}$ ).
\end{abstract}

\section{INTRODUCTION}

In order to characterize the cultivable part of the bacterioplankton of the North Sea, a water sample was investigated that was taken at a distance of $2 \mathrm{~km}$ from the island of Helgoland (10 $\mathrm{m}$ depth). Samples were

Published online ahead of print on 5 March 2004 as DOI 10.1099/ ijs.0.02850-0.

†Present address: Bayer AG, D-51368 Leverkusen, Germany.

Abbreviation: DMSP, dimethylsulfiopropionate.

The EMBL/GenBank/DDBJ accession number for the 16S rRNA gene sequence of HEL- $45^{\top}$ is AJ550939. immediately serially diluted and spread plated on marine agar media. After 2 weeks incubation, approximately 100 colonies were picked at random from plates with the highest sample dilution. The isolates can therefore be expected to belong to the more abundant of the cultivable bacteria, which grow under these conditions, at that particular sampling date. Partial sequencing (forward primer F27, about 500 base pairs of the sequence) of $16 \mathrm{~S}$ rRNA genes of the isolates showed that approximately $50 \%$ showed less than $97 \%$ sequence similarity to described species. Sixteen isolates fell into the so-called Roseobacter lineage (Eilers et al., 2001), a cluster of genera phylogenetically related to the genus Roseobacter within the 'Alphaproteobacteria'. These 
bacteria have attracted interest over the last few years because they are the closest cultivated relatives of the second most abundant uncultivated lineage in the marine picoplankton, the SAR83 cluster (Giovannoni \& Rappé, 2000; Rappé et al., 2000).

Cultivated representatives of the Roseobacter lineage display interesting physiological capabilities that may be of great importance for the marine ecosystem, e.g. aerobic anoxygenic photosynthesis (Yurkov \& Beatty, 1998a), the turnover of the greenhouse gas dimethylsulfoniopropionate (DMSP) (Zubkov et al., 2001) or the production of sodium-channel blocking toxins, which has been found in Sulfitobacter strains from toxic dinoflagellates (Vasquez et al., 2001, 2002).

Of the Roseobacter clade strains isolated from the Helgoland water sample, one group of strains (HEL-10 ${ }^{\mathrm{T}}$, HEL-43, HEL-26) was only distantly related to any of the described genera in this group and has recently been described as Jannaschia helgolandensis (Wagner-Döbler et al., 2003). Here, we report the description of strain HEL- $45^{\mathrm{T}}$, which is phylogenetically related to both Sulfitobacter and Staleya and produces a number of interesting secondary metabolites, which were analysed by Kampen (2001), Schröder (2002) and Lurtz et al. (2002) (Fig. 1). These authors identified indole and several indole derivatives, e.g. indole-3carboxylic-thiomethylester, 3-indole-carbaldehyde and 3,3-bis-(indol-3-yl)-propane-1,2-diol. Moreover, bioactive compounds were found. Three cyclic dipeptides were identified, namely cyclo-(Leu,Pro), cyclo-(Phe,Pro) and cyclo-(Tyr,Pro), which are known to have weak antiviral, antibiotic and antitumour activity (Milne et al., 1998). In addition, tryptanthrin was found, which is known to have activity against some Gram-positive bacteria as well as fungi
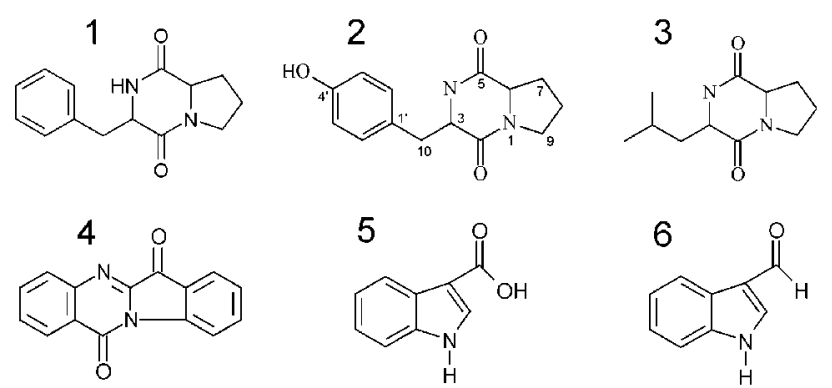<smiles>O=C(O)c1c[nH]c2ccccc12</smiles><smiles>O=Cc1c[nH]c2ccccc12</smiles><smiles>CSC(=O)c1c[nH]c2ccccc12</smiles>

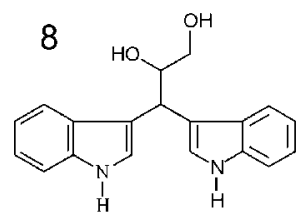

of the genera Trichophyton and Microsporum (Honda et al., 1979).

\section{METHODS}

Isolation of strain HEL-45 ${ }^{\mathbf{T}}$. A water sample was taken from $10 \mathrm{~m}$ depth using a Ruttner sampler at the 'Tiefe Rinne' approximately $2 \mathrm{~km}$ offshore of the island of Helgoland in the North Sea $\left(54^{\circ} 08^{\prime} \mathrm{N}\right.$ $7^{\circ} 52^{\prime}$ E) on 23 September 1998. The water temperature was $15 \cdot 5{ }^{\circ} \mathrm{C}$, oxygen content $8 \cdot 1 \mathrm{mg} \mathrm{l}^{-1}$ and Secchi disc visibility was $5 \cdot 5 \mathrm{~m}$. The sample was immediately transported to the laboratory and processed. An aliquot $(100 \mu \mathrm{l})$ was serially diluted $\left(10^{-1}, 10^{-2}\right.$, $\left.10^{-3}\right)$ in sterile-filtered $(0 \cdot 2 \mu \mathrm{m})$, autoclaved sea water. Subsamples $(50 \mu \mathrm{l})$ were spread on agar plates with DSMZ medium $172[1.0 \mathrm{~g}$ yeast extract (Difco), $1.0 \mathrm{~g}$ tryptone (Difco), $24 \cdot 7 \mathrm{~g} \mathrm{NaCl}, 0.7 \mathrm{~g}$ $\mathrm{KCl}, 6 \cdot 3 \mathrm{~g} \mathrm{MgSO}_{4} .7 \mathrm{H}_{2} \mathrm{O}, 4.6 \mathrm{~g} \mathrm{MgCl}_{2} .6 \mathrm{H}_{2} \mathrm{O}, 1 \cdot 2 \mathrm{~g} \mathrm{CaCl} 2.2 \mathrm{H}_{2} \mathrm{O}$, $0 \cdot 2 \mathrm{~g} \mathrm{NaHCO}_{3}, 15 \mathrm{~g}$ agar (Difco), $1000 \mathrm{ml}$ distilled water] containing $0.002 \%$ cycloheximide. Colonies from the highest dilution were picked and restreaked several times for purification.

Culture conditions. Strain HEL- $45^{\mathrm{T}}$ was initially isolated from the so-called marine cytophaga medium (DSMZ medium 172). Routine culturing using a modified Luria-Bertani agar medium, containing additional sea salts (designated LBSS: $10.0 \mathrm{~g}$ tryptone, $5.0 \mathrm{~g}$ yeast extract, $10.0 \mathrm{~g} \mathrm{NaCl}, 14.0 \mathrm{~g}$ sea salts, $15.0 \mathrm{~g}$ agar, in $1000 \mathrm{ml}$ distilled water) was found to be more suitable. Working stocks of the isolate were preserved in glycerol. Storage was carried out by inoculating $5 \mathrm{ml}$ LBSS broth with a loopful of cell material and shaking for $2-3$ days at $30^{\circ} \mathrm{C}$. Aliquots of $1.5 \mathrm{ml}$ of the suspension were centrifuged $(7000 \mathrm{~g}, 5 \mathrm{~min})$, and the supernatant was discarded. After resuspending the pellet in $500 \mu \mathrm{l}$ fresh LBSS broth, $750 \mu \mathrm{l}$ sterile glycerol $(99.5 \% \mathrm{w} / \mathrm{v})$ was added and mixed. The suspension was then equilibrated on ice for $30 \mathrm{~min}$, followed by freezing at $-18^{\circ} \mathrm{C}$ for $2 \mathrm{~h}$ and final storage at $-70^{\circ} \mathrm{C}$. For reactivation, $50 \mu \mathrm{l}$ of the suspension was recultivated by streaking on LBSS agar.

Determination of physiological characteristics. A loopful of cell material of strain HEL- $45^{\mathrm{T}}$ was taken from a fresh culture on solid LBSS medium. A suspension corresponding to McFarland standard $1\left(\mathrm{OD}_{550}=0 \cdot 25\right.$; bioMérieux $)$ was prepared in $10 \mathrm{ml}$ saline buffer supplemented with $2 \%(\mathrm{w} / \mathrm{v})$ sea salts (Sigma). The optical density was adjusted by addition of either buffer or cell material. One drop of this suspension was added to each of the test tubes or test plates. Incubation of the test samples was performed at $25^{\circ} \mathrm{C}$.

The temperature range for growth was tested in LBSS broth from 4 to $60{ }^{\circ} \mathrm{C}$, and halotolerance was tested in medium devoid of $\mathrm{NaCl}$ with 0 , $1,3,5,7,10,13$ or $15 \%(\mathrm{w} / \mathrm{v})$ sea salts added. The $\mathrm{pH}$ range for growth was determined in a range from 5.0 to 11.0 in steps of one $\mathrm{pH}$ unit. The $\mathrm{pH}$ value was adjusted by addition of either $\mathrm{HCl}$ or $\mathrm{NaOH}$. All tests were set up in duplicate. Anaerobic growth was also tested on agar plates containing LBSS medium, incubated in an anaerobic jar.

The following physiological tests were carried out according to methods described by Gordon et al. (1973): catalase reaction, oxidase reaction, presence of urease, decomposition of Tween 80, starch hydrolysis and nitrite production.

Gelatin liquefaction was tested following the method of Gerhardt et al. (1981) in that plates of LBSS containing $0 \cdot 4 \%$ gelatin were incubated with strain HEL- $45^{\mathrm{T}}$ for 7 and 14 days. Plates were then flooded with warm $\left(55^{\circ} \mathrm{C}\right) 0.5 \mathrm{M}$ sulfuric acid, saturated with $\mathrm{Na}_{2} \mathrm{SO}_{4}$. A resulting clear circular zone around the colony indicated digestion of the gelatin. Hydrolysis of aesculin was tested in accordance with Lanyi (1987) in a medium consisting of $10.0 \mathrm{~g}$ Bacto-peptone, $1.0 \mathrm{~g}$ sodium citrate, $1 \cdot 0 \mathrm{~g}$ aesculin and $0.05 \mathrm{~g}$ ferric citrate in $1000 \mathrm{ml}$ water at $\mathrm{pH} 6 \cdot 8-7 \cdot 0$. 
Carbon utilization was tested in standard mineral base medium (Stanier et al., 1966) containing $0 \cdot 2 \%$ of the carbon source. A negative control without carbon source was also included. As no growth could be observed in any of these tests, they were repeated with the addition of three drops of sterile $0 \cdot 1 \%$ yeast extract to each of the test tubes. Even under these conditions, the negative control did not show any growth. The tests were examined for growth daily for up to 2 weeks until no further growth in the test tubes was observed. Carbon sources thus tested were: glucose, acetate, propionate, butyrate, pyruvate, DL-lactate, L-aspartate, asparagine, L-glutamate, L-proline, L-serine, DL-alanine, L $(+)$-ornithine, succinate and methanol. Physiological reactions were also tested using the substrate panel of the API $20 \mathrm{NE}$ and API $50 \mathrm{CH}$ systems (bioMérieux). Additional carbon sources covered by these systems were: D-arabinose, mannose, mannitol, $\mathrm{N}$ acetylglucosamine, maltose, gluconate, caprate, adipate, malate, citrate, phenylacetate, glycerol, erythritol, L-arabinose, ribose, D-xylose, $\mathrm{L}$-xylose, adonitol, methyl $\beta$-xyloside, galactose, $\mathrm{D}$-fructose, L-sorbose, rhamnose, dulcitol, inositol, sorbitol, methyl $\alpha$-D-mannoside, methyl $\alpha$-D-glucoside, amygdalin, arbutin, aesculin, salicin, cellobiose, lactose, melibiose, sucrose, trehalose, inulin, melezitose, D-raffinose, starch, glycogen, xylitol, $\beta$-gentiobiose, D-turanose, D-lyxose, D-tagatose, D-fucose, L-fucose, D-arabitol, L-arabitol, 2-ketogluconate and 5-ketogluconate.

Carbon sources that tested negatively but are not included in Table 1 (see Results and Discussion) owing to a lack of data for the phylogenetic relatives are: D-arabinose, maltose, caprate, phenylacetate, erythritol, L-arabinose, ribose, D-xylose, L-xylose, adonitol, methyl $\beta$-xyloside, L-sorbose, dulcitol, inositol, tryptophan, methyl $\alpha$ D-mannoside, methyl $\alpha$-D-glucoside, amygdalin, arbutin, salicin, melibiose, trehalose, inulin, melezitose, D-raffinose, starch, glycogen, xylitol, $\beta$-gentiobiose, D-turanose, D-lyxose, D-tagatose, D-fucose, L-arabitol, 2-ketogluconate and 5-ketogluconate.

Reduction of nitrate, fermentation of D-glucose, presence of arginine dihydrolase, presence of urease, aesculin hydrolysis, gelatin hydrolysis and presence of $\beta$-galactosidase were additionally tested by reading and interpreting the corresponding API tests.

Microscopic investigations. Primary morphological characterization was by light microscopy, including phase-contrast observations. The size and ultrastructure of the cells were determined by electron microscopy. Cell morphology was investigated using slides covered with $2 \%(\mathrm{w} / \mathrm{v})$ agar (dissolved in water). Transmission electron microscopic investigations were carried out as described by Rheims et al. (1999). Staining for poly- $\beta$-hydroxybutyrate was performed as follows. A heat-fixed film was prepared on a microscope slide from a drop of culture fluid. The slide was immersed in Sudan black B $(0.3 \% \mathrm{w} / \mathrm{v}$ in ethanol) for $5-15 \mathrm{~min}$, drained and air-dried on blotting paper. The slide was then immersed in xylene and withdrawn several times, and then blotted dry. For counterstaining, the slide was immersed in an aqueous safranin solution $(0.5 \% \mathrm{w} / \mathrm{v})$ for 5-10 s, rinsed with tap water and blotted dry. Examination was under the light microscope with and without phase-contrast optics. Poly- $\beta$-hydroxybutyrate inclusion bodies appear blue-black and the cytoplasmic parts of the organism appear pink (following counterstaining).

Chemotaxonomy. Analysis of fatty acid methyl esters was performed with $20 \mathrm{mg}$ freeze-dried biomass as described by Labrenz et al. (1998). Respiratory lipoquinones and polar lipids were extracted from $100 \mathrm{mg}$ freeze-dried material using a two-stage extraction method and analysed as described by Tindall (1990a, b).

Determination of base composition of DNA. Isolation of DNA (Cashion et al., 1977) and determination of the DNA G+C content (mol\%) by HPLC (Mesbah et al., 1989) followed standard procedures.
DNA-DNA hybridization. DNA-DNA relatedness studies were performed by the renaturation method (Escara \& Hutton, 1980; Huß et al., 1983). Relatedness values were calculated according to the methods of Jahnke (1992).

Phylogenetic inferences. Genomic DNA was extracted from bacterial cells and purified as described by Pukall et al. (1998). The primer pair 27f (5'-GAGTTTGATCCTGGCTCAG-3') and $1527 \mathrm{r}$ (5'-AGAAAGGAGGTGATCCAGCC-3') was used for amplification of the 16S rRNA gene (Lane, 1991). Amplification of 16S rRNA gene sequences by PCR was performed as described by Pukall et al. (1999). Analysis of the 16S rRNA gene sequence obtained from isolate HEL $-45^{\mathrm{T}}$ followed the method described by Rainey et al. (1996) using the Taq DyeDeoxy Terminator cycle sequencing kit (Applied Biosystems) and an Applied Biosystems model 373A automated DNA sequencer. Sequences were aligned manually and compared to previously published sequences. These were stored in the DSMZ internal database consisting of more than 6000 16S rRNA gene sequence entries, including those from the Ribosomal Database Project (Maidak et al., 2001) and EMBL. Similarity values were transformed into genetic distance values that compensate for multiple substitutions at any given site in the sequence (Jukes \& Cantor, 1969). The neighbour-joining method contained in the PHYLIP package (Felsenstein, 1993) and the algorithm of DeSoete (1983) were used in the construction of the phylogenetic dendrogram. All analyses were performed on a SUN SparcII workstation.

\section{RESULTS AND DISCUSSION}

\section{Colony and cell morphology}

Colonies of strain HEL- $45^{\mathrm{T}}$ on agar media were whitish with a shiny surface. Single cells were irregular rods with a length of $3-5 \mu \mathrm{m}$ and a width of $1 \cdot 8-2 \cdot 5 \mu \mathrm{m}$ (Fig. 2). A few individual cells under microscopic investigation had a bulbous end. Some cells were observed in stages resembling branching or budding. Strain HEL $-45^{\mathrm{T}}$ could be shown to stain Gram-negatively by classical staining techniques as well as by cell lysis after the addition of $3 \%$ (w/v) KOH. As judged by microscopic investigations, HEL$45^{\mathrm{T}}$ does not form spores. White inclusion bodies were often present, which were clearly not gas vesicles, as judged by transmission electronic investigations (Fig. 2, and further data not shown). These inclusion bodies stained black with Sudan black, suggesting they probably consist of poly$\beta$-hydroxybutyrate. Active motility was not observed.

\section{Physiological characteristics}

Strain HEL- $45^{\mathrm{T}}$ grew strictly aerobically. Tests for the presence of cytochrome oxidase were performed repeatedly with fresh reagent and cultures of different ages. In all cases HEL$45^{\mathrm{T}}$ showed a weakly positive reaction. The strain did not reduce nitrate to nitrite.

Growth was poor at $8{ }^{\circ} \mathrm{C}$ and continued at up to $30^{\circ} \mathrm{C}$ with an optimum temperature of $25-30^{\circ} \mathrm{C}$. The $\mathrm{pH}$ range tolerated for growth was $7 \cdot 0-9 \cdot 0$ with an optimum at $\mathrm{pH} 7 \cdot 0$. Strain HEL- $45^{\mathrm{T}}$ showed no growth in media devoid of salts. When only sodium chloride was added to the test medium, strain HEL- $45^{\mathrm{T}}$ also failed to grow. Therefore, determination of halotolerance was carried out with the 

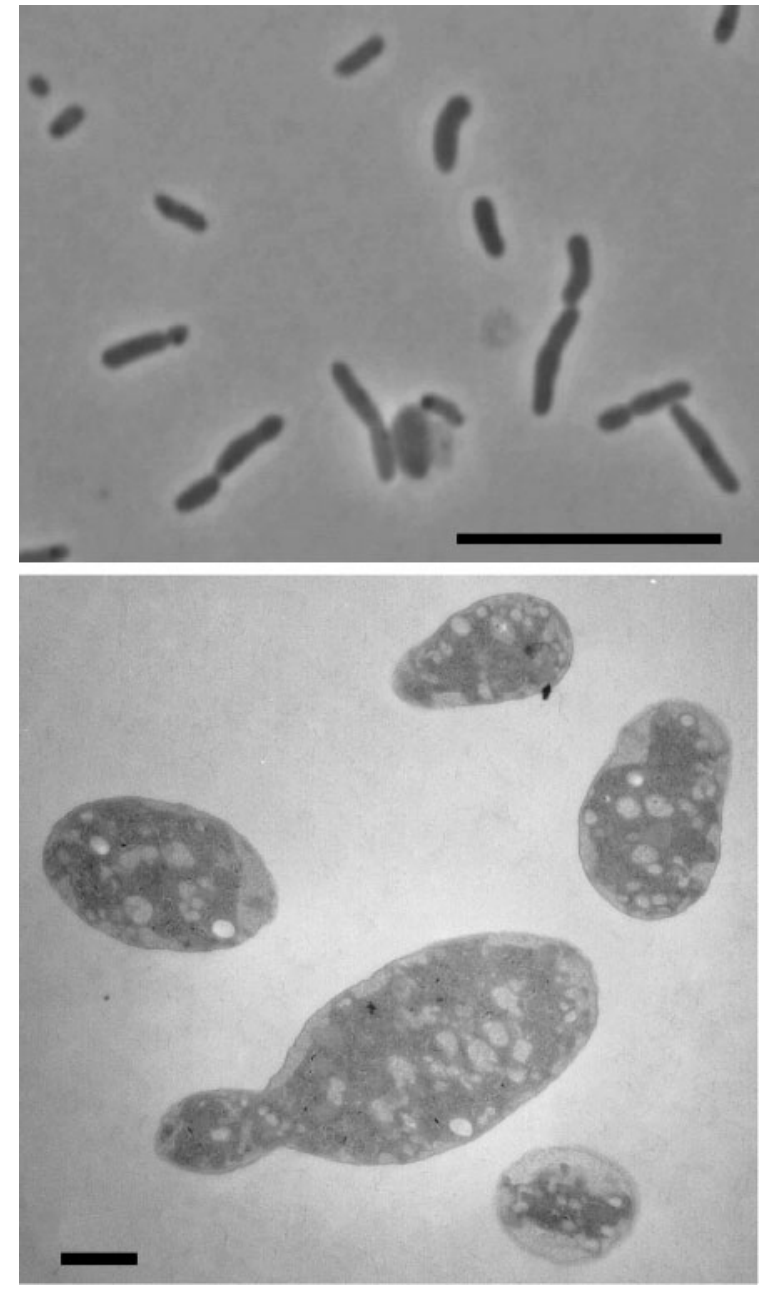

Fig. 2. Microscopic images of cells of strain $\mathrm{HEL}-45^{\top}$. Top, light microscopic image. Bar, $15 \mu \mathrm{m}$. Bottom, transmission electron microscopic image. Bar, $1.3 \mu \mathrm{m}$.

addition of commercially available sea salts. Growth started at a concentration of $1 \%$ salts and continued up to $10 \%$ with an optimum around 3-5\% (w/v).

The results of further physiological tests are summarized in Table 1. Also included are some of the literature data for the closest phylogenetic relatives as judged by $16 \mathrm{~S}$ rRNA gene sequence analysis. Further carbon sources that were tested but gave negative results are listed in Methods. Test results for hydrolysis of gelatin, starch, Tween 80 , urea and aesculin were negative.

\section{Phylogenetic inferences}

Analysis of the nearly complete $16 \mathrm{~S}$ rRNA gene sequence indicated that strain HEL- $45^{\mathrm{T}}$ shared $97 \cdot 4 \%$ sequence similarity with the sequence of Sulfitobacter mediterraneus DSM $12244^{\mathrm{T}}$. Similarity values determined for the other species of the genus Sulfitobacter and for Staleya guttiformis and Roseobacter litoralis ranged between $97 \cdot 0$ and $96 \cdot 4 \%$ (Fig. 3).

When the almost complete 16S rRNA gene sequence of strain HEL- $45^{\mathrm{T}}$ was compared with those of Sulfitobacter mediterraneus DSM $12244^{\mathrm{T}}$, Sulfitobacter pontiacus DSM $10014^{\mathrm{T}}$, Sulfitobacter brevis DSM $11443^{\mathrm{T}}$ and Staleya guttiformis DSM $11458^{\mathrm{T}}$, several nucleotide positions could been identified, which can be considered as signature nucleotides comprising specific base-pair exchanges. At the four positions 132-230 (G:C), 140-223 (C:G), 144-178 $(\mathrm{G}: \mathrm{C})$ and 1356-1366 (G:C), given according to the Escherichia coli nomenclature (Brosius et al., 1978), base pairs of HEL- $45^{\mathrm{T}}$ were different from those of Sulfitobacter species or Staleya guttiformis. For those strains, the following combinations were found at the same positions: 132-230, A: U (all); 140-223, U:G (Sulfitobacter mediterraneus), $\mathrm{U}: \mathrm{A}$ (others); 144-178, A: U (all); and 1356-1366, U:A (all).

DNA-DNA relatedness determined by the spectrophotometric method revealed only a low value of $21 \cdot 2 \%$ between strains HEL $-45^{\mathrm{T}}$ and Sulfitobacter mediterraneus DSM $12244^{\mathrm{T}}$. The $\mathrm{G}+\mathrm{C}$ content of the DNA for strain HEL$45^{\mathrm{T}}$ was determined to be $60 \cdot 1 \mathrm{~mol} \%$.

\section{Chemotaxonomic properties}

Analysis of the respiratory quinone composition of strain HEL- $45^{\mathrm{T}}$, Sulfitobacter pontiacus DSM $10014^{\mathrm{T}}$, Sulfitobacter brevis DSM $11443^{\mathrm{T}}$, Sulfitobacter mediterraneus DSM $12244^{\mathrm{T}}$ and Staleya guttiformis DSM $11458^{\mathrm{T}}$ indicated that $\mathrm{Q} 10$ predominated in all strains. The presence of Q10 as the dominant respiratory quinone is a feature of many, but not all, members of the 'Alphaproteobacteria'. Although Q10 is also found in Legionella species ('Gammaproteobacteria'), it is not the sole, major component in these bacteria, making the presence of Q10 as the sole major respiratory quinone specific to members of the 'Alphaproteobacteria'.

The polar lipid composition of all strains showed a high degree of similarity, with the phospholipids phosphatidyl glycerol, phosphatidyl choline and phosphatidyl ethanolamine all present. In addition, an aminolipid was also present. Diphosphatidyl glycerol was not universally present. The fatty acid composition of all strains gave patterns in which $18: 1 \omega 7 c$ predominated, but different groupings could be distinguished on the basis of the remaining fatty acids; these are listed in Table 2.

As also noted by Labrenz et al. (2000), we have been able to confirm some degree of infrastructure within this group based on the polar lipid and fatty acid composition. We observed some differences in the relative percentages of the fatty acids compared to previous work, although small changes are to be expected in the relative composition owing to slight differences in conditions of cultivation, and should not be overemphasized when evaluating the data. Closer examination of the fatty acid composition revealed three 
Table 1. Selected physiological properties of strain $\mathrm{HEL}-45^{\top}$ compared to its closest phylogenetic relatives (as judged by $16 \mathrm{~S}$ rRNA gene sequence analysis)

Species/strains: 1, HEL-45 ${ }^{\mathrm{T}}$; 2, Sulfitobacter mediterraneus (data from Pukall et al., 1999); 3, Sulfitobacter pontiacus (Sorokin, 1995); 4, Sulfitobacter brevis (Labrenz et al., 2000); 5, Staleya guttiformis (Labrenz et al., 2000). +, Positive reaction/growth detectable; W, weakly positive reaction; -, negative reaction/no growth detectable; ND, not determined.

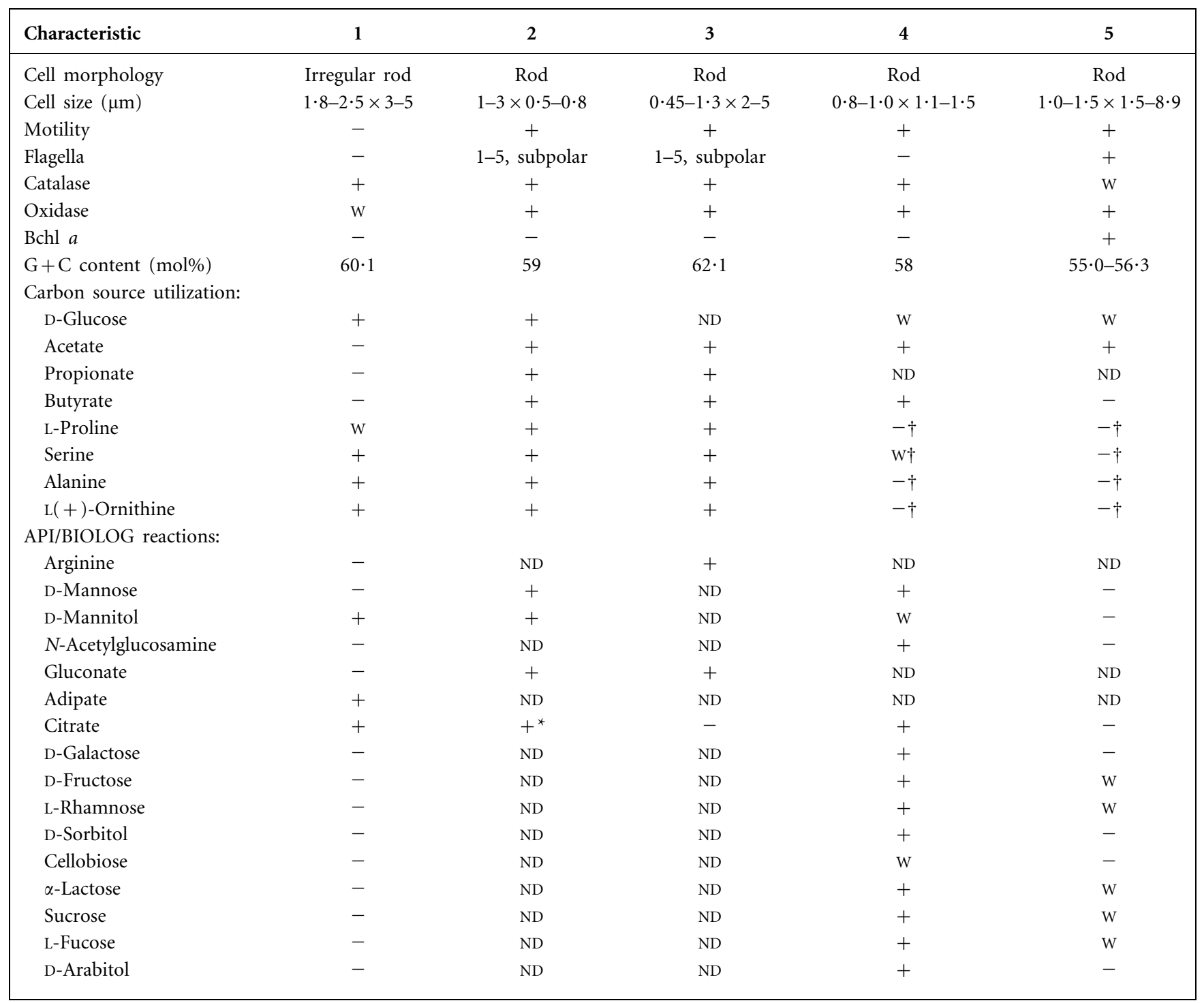

${ }^{\star}$ Stimulated in media containing yeast extract or biotin.

$\dagger$ Determined in BIOLOG microtitre plates.

major groups: (i) Sulfitobacter pontiacus DSM 10014 / Sulfitobacter brevis DSM $11443^{\mathrm{T}}$, (ii) strain HEL- $45^{\mathrm{T}}$ and (iii) Staleya guttiformis DSM $11458^{\mathrm{T}} /$ Sulfitobacter mediteraneus DSM $12244^{\mathrm{T}}$. In particular, although all members of this group produced $3-\mathrm{OH} 10: 0$, there were differences in the distribution of other 3-OH fatty acids. It should be noted that unambiguous proof is not presented here that the $3-\mathrm{OH}$ $12: 1$ or $3-\mathrm{OH} 14: 1$ are not 3 -oxo derivatives, which are very difficult to distinguish on the basis of mass spectrometry alone. Sulfitobacter pontiacus DSM $10014^{\mathrm{T}}$ and Sulfitobacter brevis DSM $11443^{\mathrm{T}}$ produced 3-OH 12:0 and 3-OH 14:1 (or 3-oxo 14:0), whereas Staleya guttiformis DSM $11458^{\mathrm{T}}$ and Sulfitobacter mediteraneus DSM $12244^{\mathrm{T}}$ produced only 3-OH 14:1 (or 3-oxo 14:0) and strain HEL-45 ${ }^{\mathrm{T}}$ produced 3-OH 12:1 (or 3-oxo 12:0). For the fatty acids identified here as $3-\mathrm{OH} 12: 1$ (or 3-oxo 12:0), $3-\mathrm{OH} 12: 0$ and $3-\mathrm{OH}$ 14:1 (3-oxo 14:0), all appeared to be amide linked.

Although it may not be possible to determine with absolute certainty the branching order within the group defined by members of the genera Staleya-Sulfitobacter-strain HEL $45^{\mathrm{T}}$ based on the 16S rRNA gene sequences, it is sufficient that 


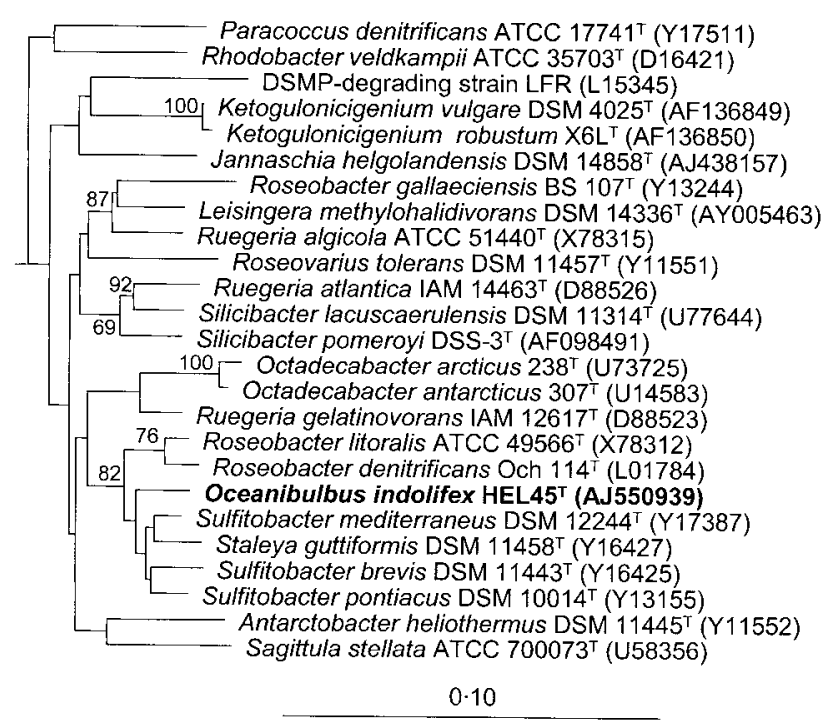

Fig. 3. Dendrogram of $16 \mathrm{~S}$ rRNA gene sequence relatedness showing the position of strain HEL- $45^{\top}$ next to its nearest identified neighbours within the 'Alphaproteobacteria'. The tree was calculated by the neighbour-joining method from almost complete sequences. The percentage of 1000 bootstrap resamplings that support branching points above $65 \%$ confidence is indicated. The scale bar represents 10 nucleotide substitutions per 100 sequence positions. The tree was rooted with $E$. coli as an outgroup. Sequence accession numbers are given in parentheses. groups be clearly distinguished from one another (Tindall, 1994), there being a distinct and subtle difference between phyletic lineages and phyletic groups (Gilmour, 1940). It is particularly interesting that Sulfitobacter pontiacus DSM $10014^{\mathrm{T}} /$ Sulfitobacter brevis DSM $11443^{\mathrm{T}}$, strain HEL-45 and Staleya guttiformis DSM $11458^{\mathrm{T}} /$ Sulfitobacter mediteraneus DSM $12244^{\mathrm{T}}$ form three distinct groups based on their chemical composition.

The data presented here are consistent with what has been reported previously in the literature, where the absolute branching order of taxa showing short internal branches cannot be determined unambiguously based on the $16 \mathrm{~S}$ rRNA gene sequence data alone. Ludwig et al. (1998) proposed that in such cases the branches should be collapsed to give a 'collapsed clade'. In such cases, the $16 \mathrm{~S}$ rRNA gene sequence data can only give a polychotomy at best, which would suggest that this group of strains represents a single genus. However, the chemical composition clearly indicates that there is infrastructure within this group and may be used to define at least three subgroupings. These groupings appear to be no less significant than those defined by other genera in which the chemical composition, 16S rRNA gene sequences and biochemical/physiological data have been taken into consideration in this subgroup of the 'Alphaproteobacteria' (see Labrenz et al., 1998, 1999, 2000). It should be noted that the $16 \mathrm{~S}$ rRNA gene sequence similarity between the strains is greater than $96 \%$, suggesting that the often used value of $95 \%$ similarity for

Table 2. Percentage composition of the fatty acids present in strain HEL- $45^{\top}$

Strains: 1, HEL-45 ${ }^{\mathrm{T}}$; 2, Staleya guttiformis DSM $11458^{\mathrm{T}} ; 3$, Sulfitobacter mediterraneus DSM $12244^{\mathrm{T}}$; 4, Sulfitobacter pontiacus DSM $10014^{\mathrm{T}}$; 5, Sulfitobacter brevis DSM $11443^{\mathrm{T}}$. Method 1 (M1): ester-linked fatty acids; method 2: ester- and amide-linked fatty acids (see Tindall, 1990a, b).

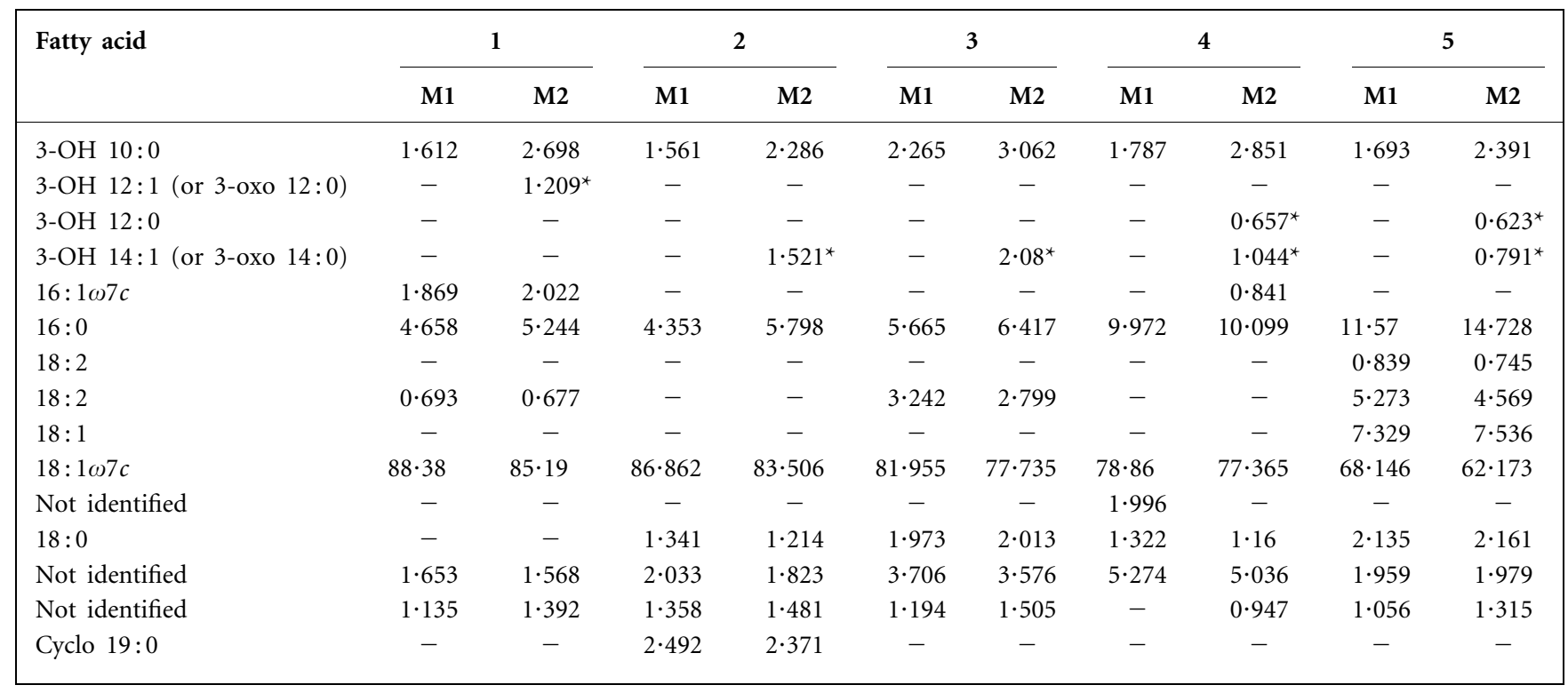

*Presumptive amide-linked fatty acids. 
delineating genera would not take into account the chemical diversity of this group. In fact, using the value of $95 \%$ similarity as a cut-off value would imply that all these species should be placed in the genus Roseobacter.

In the case of strain HEL- $45^{\mathrm{T}}$, we interpret the chemical composition of the cell as being indicative of the fact that this strain, which obviously represents a novel species, should also be placed in a new genus. The chemical heterogeneity evident within the genus Sulfitobacter, as currently defined, would justify transferring Sulfitobacter mediterraneus to the genus Staleya. However, the ability for aerobic anoxygenic photosynthesis has been found in Staleya and is a significant physiological trait that has to be weighed against the chemical composition of the cells (Yurkov \& Beatty, 1998a, b). In the absence of additional information, and in view of the needs of the end users of bacterial systematics, we therefore refrain at present from transferring Sulfitobacter mediterraneus to the genus Staleya.

\section{Description of Oceanibulbus gen. nov.}

Oceanibulbus (O.ce.a.ni.bul'bus. L. n. oceanus the sea; L. n. bulbus onion; N.L. masc. n. Oceanibulbus onion-like bacterium from the sea).

Gram-negative, non-motile irregular rods with a tendency to form slightly swollen ends. On LBSS agar, the strain develops colonies within 3-5 days. They do not form spores. Bacteriochlorophyll $a$ is not produced. Growth is poor at $15^{\circ} \mathrm{C}$ and optimal at $25-30^{\circ} \mathrm{C}$. pH optimum for growth is $7 \cdot 0-8 \cdot 0$. Strictly aerobic, non-fermentative heterotrophs. Inclusion bodies often present. In media devoid of salts or containing only sodium chloride, no growth is observed. Growth at $1-7 \%(\mathrm{w} / \mathrm{v})$ sea salts. They show a weakly positive reaction in tests for cytochrome oxidase and do not reduce nitrate to nitrite. The predominant respiratory quinone present is ubiquinone $10(\mathrm{Q} 10)$. The major polar lipids are phosphatidyl glycerol, diphosphatidyl glycerol, phosphatidyl choline, phosphatidyl ethanolamine and an aminolipid. The fatty acids comprise $18: 1 \omega 7 c, 18: 0,16: 1 \omega 7 c$, $16: 0,3-\mathrm{OH} 10: 0,3-\mathrm{OH} 12: 1$ (or 3-oxo 12:0) and traces of an $18: 2$ fatty acid. Among the hydroxylated fatty acids only 3-OH 12:1 (or 3-oxo 12:0) appears to be amide linked, whereas 3-OH 10:0 appears to be ester linked. The type species is Oceanibulbus indolifex.

\section{Description of Oceanibulbus indolifex sp. nov.}

Oceanibulbus indolifex (in.do'li.fex. N.L. masc. n. indolum indole; L. masc. suff. -fex from L. v. facio to make; N.L. masc. adj. indolifex making indole/the indole maker).

Displays the following properties in addition to those given in the genus description. Cells are variable in size $(3-5 \mu \mathrm{m}$ long, $1 \cdot 8-2 \cdot 5 \mu \mathrm{m}$ wide). They have inclusion bodies that appear white in transmission electron microscopic sections and consist of poly- $\beta$-hydroxybutyrate. Catalase-positive and weakly oxidase-positive. The $\mathrm{G}+\mathrm{C}$ content of the type strain is $60 \cdot 1 \mathrm{~mol} \%$. Cells grown on LBSS develop small, whitish, shiny colonies within 3-5 days. Hydrolysis of gelatin, starch, Tween 80, urea and aesculin is not observed. Strains do not reduce nitrate to nitrite. Carbon source utilization in standard mineral base medium (Stanier et al., 1966) containing $0 \cdot 2 \%$ of the carbon source and $0 \cdot 1 \%$ yeast extract shows utilization of D-glucose, pyruvate, DLlactate, serine, ornithine, alanine, asparagine, L-aspartate, L-glutamate, L-proline, succinate, mannitol, adipate, malate, citrate and glycerol. Chemotaxonomic properties and other characteristics are as for the genus.

The type strain, strain HEL $-45^{\mathrm{T}}\left(=\mathrm{DSM} 14862^{\mathrm{T}}=\mathrm{NCIMB}\right.$ $13983^{\mathrm{T}}$ ), was originally obtained from a North Sea water sample from a depth of $10 \mathrm{~m}$. The EMBL accession number of the 16S rRNA gene sequence is AJ550939.

\section{ACKNOWLEDGEMENTS}

We wish to thank I. Pubantz, E. Haase, A. Frühling and B. Sträubler for their assistance. H. Lünsdorf is thanked for providing electron microscopic images and $\mathrm{H}$. Biebl for helpful discussions and critical comments on the manuscript.

\section{REFERENCES}

Brosius, J., Palmer, M. L., Kennedy, P. J. \& Noller, H. F. (1978). Complete nucleotide sequence of a $16 \mathrm{~S}$ ribosomal RNA gene from Escherichia coli. Proc Natl Acad Sci U S A 75, 4801-4805.

Cashion, P., Holder-Franklin, M. A., McCully, J. \& Franklin, M. (1977). A rapid method for the base ratio determination of bacterial DNA. Anal Biochem 81, 461-466.

DeSoete, G. (1983). A least squares algorithm for setting additive trees to proximity data. Psychometrika 48, 621-626.

Eilers, H., Pernthaler, J., Peplies, J., Glöckner, F. O., Gerdts, G. \& Amann, R. (2001). Isolation of novel pelagic bacteria from the German bight and their seasonal contributions to surface picoplankton. Appl Environ Microbiol 67, 5134-5142.

Escara, J. F. \& Hutton, J. R. (1980). Thermal stability and renaturation of DNA in dimethyl sulfoxide solutions: acceleration of the renaturation rate. Biopolymers 19, 1315-1327.

Felsenstein, J. (1993). PHYLIP (Phyogenetic Inference Package), version 3.5.1. Distributed by the author. Department of Genetics, University of Washington, Seattle, USA.

Gerhardt, P., Murray, R. G. E., Costilow, R. N., Nester, E. W., Wood, W. A., Krieg, N. R. \& Phillips, R. B. (1981). Manual of Methods for General Bacteriology. Washington, DC: American Society for Microbiology.

Gilmour, J. S. L. (1940). Taxonomy and philosophy. In The New Systematics, pp. 461-474. Edited by J. Huxley. London: Systematics Association.

Giovannoni, S. J. \& Rappé, M. S. (2000). Evolution, diversity and molecular ecology of marine prokaryotes. In Microbial Ecology of the Ocean, pp. 47-84. Edited by D. L. Kirchman. New York: Wiley.

Gordon, R. E., Haynes, W. C. \& Pang, C. H. (1973). The genus Bacillus. Agricultural Handbook 427. Washington, DC: US Department of Agriculture.

Honda, G., Tabata, M. \& Tsuda, M. (1979). The antimicrobial specificity of tryptanthrin. Planta Med 37, 172-174. 
Huß, V. A. R., Festl, H. \& Schleifer, K.-H. (1983). Studies on the spectrophotometric determination of DNA hybridization from renaturation rates. Syst Appl Microbiol 4, 184-192.

Jahnke, K.-D. (1992). Basic computer program for evaluation of spectroscopic DNA renaturation data from Gilford System 2600 spectrophotometer on a PC/XT/AT type personal computer. J Microbiol Methods 15, 61-73.

Jukes, T. H. \& Cantor, C. R. (1969). Evolution of protein molecules. In Mammalian Protein Metabolism, pp. 21-132. Edited by $\mathrm{N}$. Munro. New York: Academic Press.

Kampen, I. (2001). Studien zu Wachstum und Metabolitenbildung bei neuen Bakterien aus der Nordsee. Diploma thesis, Technical University of Braunschweig.

Labrenz, M., Collins, M. D., Lawson, P. A., Tindall, B. J., Braker, G. \& Hirsch, P. (1998). Antarctobacter heliothermus gen. nov., sp. nov., a budding bacterium from hypersaline and heliothermal Ekho Lake. Int J Syst Bacteriol 48, 1363-1372.

Labrenz, M., Collins, M. D., Lawson, P. A., Tindall, B. J., Schumann, P. \& Hirsch, P. (1999). Roseovarius tolerans gen. nov., sp. nov., a budding bacterium with variable bacteriochlorophyll a production from hypersaline Ekho Lake. Int J Syst Bacteriol 49, 137-147.

Labrenz, M., Tindall, B. J., Lawson, P. A., Collins, M. D., Schumann, P. \& Hirsch, P. (2000). Staleya guttiformis gen. nov., sp. nov. and Sulfitobacter brevis sp. nov., $\alpha$-3-Proteobacteria from hypersaline, heliothermal and meromictic antarctic Ekho Lake. Int J Syst Evol Microbiol 50, 303-313.

Lane, D. J. (1991). 16S-23S rRNA sequencing. In Nucleic Acid Techniques in Bacterial Systematics, pp. 125-175. Edited by E. Stackebrandt \& M. Goodfellow. Chichester: Wiley.

Lanyi, B. (1987). Classical and rapid identification methods for medically important bacteria. Methods Microbiol 19, 1-67.

Ludwig, W., Strunk, O., Klugbauer, S. \& 9 other authors (1998). Bacterial phylogeny based on comparative sequence analysis. Electrophoresis 19, 554-568.

Lurtz, V., Nguyen, S., El-Ghezal, A., Wagner-Döbler, I., Laatsch, H. \& Lang, S. (2002). Bioreactor cultivations of metabolically variable North Sea bacteria. Poster presentation, 3rd European Conference on Marine Natural Products, 15-20 September 2002, Elmau Castle, Germany.

Maidak, B. L., Cole, J. R., Lilburn, T. G. \& 7 other authors (2001). The RDP-II (Ribosomal Database Project). Nucleic Acids Res 29, 173-174.

Mesbah, M., Premachandran, U. \& Whitman, W. B. (1989). Precise measurement of the $\mathrm{G}+\mathrm{C}$ content of deoxyribonucleic acid by highperformance liquid chromatography. Int J Syst Bacteriol 39, 159-167.

Milne, P. J., Hunt, A. L., Rostoll, K., van der Walt, J. J. \& Graz, C. J. (1998). The biological activity of selected cyclic dipeptides. J Pharm Pharmacol 50, 1331-1337.

Pukall, R., Brambilla, E. \& Stackebrandt, E. (1998). Automated fragment length analysis of fluorescently-labeled 16S rDNA after digestion with 4-base cutting restriction enzymes. I Microbiol Methods 32, 55-64.

Pukall, R., Buntefuß, D., Frühling, A., Rohde, M., Kroppenstedt, R. M., Burghardt, J., Lebaron, P., Bernard, L. \& Stackebrandt, E. (1999).
Sulfitobacter mediterraneus sp. nov., a new sulfite-oxidizing member of the $\alpha$-Proteobacteria. Int J Syst Bacteriol 49, 513-519.

Rainey, F. A., Ward-Rainey, N., Kroppenstedt, R. M. \& Stackebrandt, E. (1996). The genus Nocardiopsis represents a phylogenetically coherent taxon and a distinct actinomycete lineage: proposal of Nocardiopsaceae fam. nov. Int J Syst Bacteriol 46, 1088-1092.

Rappé, M. S., Vergin, K. \& Giovannoni, S. J. (2000). Phylogenetic comparisons of a coastal bacterioplankton community with its counterparts in open ocean and freshwater systems. FEMS Microbiol Ecol 33, 219-232.

Rheims, H., Frühling, A., Schumann, P., Rohde, M. \& Stackebrandt, E. (1999). Bacillus silvestris sp. nov., a new member of the genus Bacillus that contains lysine in its cell wall. Int J Syst Bacteriol 49, 795-802.

Schröder, D. (2002). Untersuchungen zum Sekundärmetabolismus arktischer und antarktischer Meereisbakterien. PhD thesis, University of Göttingen.

Sorokin, D. Y. (1995). Sulfitobacter pontiacus gen. nov., sp. nov. a new heterotrophic bacterium from the Black Sea, specialised on sulfite oxidation. Microbiology (English translation of Mikrobiologiya) 64, 295-305.

Stanier, R. Y., Palleroni, N. J. \& Doudoroff, M. (1966). The anaerobic pseudomonads: a taxonomic study. J Gen Microbiol 43, 159-271.

Tindall, B. J. (1990a). A comparative study of the lipid composition of Halobacterium saccharovorum from various sources. Syst Appl Microbiol 13, 128-130.

Tindall, B. J. (1990b). Lipid composition of Halobacterium lacusprofundi. FEMS Microbiol Lett 66, 199-202.

Tindall, B. J. (1994). Chemical analysis of Archaea and Bacteria: a critical evaluation of its use in taxonomy and identification. In Bacterial Diversity and Systematics (FEMS Symposium no. 75), pp. 243-258. Edited by F. G. Priest, A. Ramos-Cormenzana \& B. J. Tindall. New York: Plenum.

Vasquez, M., Gruttner, C., Gallacher, S. \& Moore, E. R. B. (2001). Detection and characterization of toxigenic bacteria associated with Alexandrium catenella and Aulacomya ater contaminated with PSP. J Shellfish Res 20, 1245-1249.

Vasquez, M., Grüttner, C., Möeller, B. \& Moore, E. R. B. (2002). Limited selection of sodium channel blocking toxin-producing bacteria from paralytic shellfish toxin-contaminated mussels (Aulacomya ater). Res Microbiol 153, 333-338.

Wagner-Döbler, I., Rheims, H., Felske, A., Pukall, R. \& Tindall, B. J. (2003). Jannaschia helgolandensis gen. nov., sp. nov., a novel abundant member of the marine Roseobacter clade from the North Sea. Int J Syst Evol Microbiol 53, 731-738.

Yurkov, V. V. \& Beatty, J. T. (1998a). Aerobic anoxygenic phototrophic bacteria. Microbiol Mol Biol Rev 62, 695-724.

Yurkov, V. \& Beatty, J. T. (1998b). Isolation of aerobic anoxygenic photosynthetic bacteria from black smoker plume waters of the Juan de Fuca Ridge in the Pacific Ocean. Appl Environ Microbiol 64, 337-341.

Zubkov, M. V., Fuchs, B. M., Archer, S. D., Kiene, R. P., Amann, R. \& Burkill, P. H. (2001). Linking the composition of bacterioplankton to rapid turnover of dissolved dimethylsulphoniopropionate in an algal bloom in the North Sea. Environ Microbiol 3, 304-311. 